\title{
Synthesis, Surface Active Properties and Cytotoxicity of Sodium N-Acyl Prolines
}

\author{
Madhumanchi Sreenu', Rachapudi Badari Narayana Prasad ${ }^{1, *}$, Pombala Sujitha ${ }^{2}$ and \\ Chityal Ganesh Kumar ${ }^{2}$ \\ ${ }^{1}$ Centre for Lipid Research, CSIR-Indian Institute of Chemical Technology (CSIR-IICT), Hyderabad 500007, Andhra Pradesh, INDIA \\ ${ }^{2}$ Medicinal Chemistry and Pharmacology Division, CSIR-Indian Institute of Chemical Technology (CSIR-IICT), Hyderabad 500 007, Andhra \\ Pradesh, INDIA
}

\begin{abstract}
Sodium $N$-acyl prolines (NaNAPro) were synthesized using mixture of fatty acids obtained from coconut, palm, karanja, Sterculia foetida and high oleic sunflower oils via Schotten-Baumann reaction in 58$\mathbf{7 5 \%}$ yields to study the synergetic effect of mixture of hydrophobic fatty acyl functionalities like saturation, unsaturation and cyclopropene fatty acids with different chain lengths and aliphatic hetero cyclic proline head group on their surface and cytotoxicity activities. The products were characterized by chromatographic and spectral techniques. The synthesized products were evaluated for their surface active properties such as surface tension, wetting power, foaming characteristics, emulsion stability, calcium tolerance, critical micelle concentration $(C M C)$ and thermodynamic properties. The results revealed that all the products exhibited superior surface active properties like $C M C$, calcium tolerance and emulsion stability as compared to the standard surfactant, sodium lauryl sulphate (SLS). In addition, palm, Sterculia foetida and high oleic sunflower fatty $N$-acyl prolines exhibited promising cytotoxicity against different tumor cell lines.
\end{abstract}

Key words: proline, mixture of fatty acids, sodium $N$-acyl prolines, surface active properties, cytotoxicity

\section{INTRODUCTION}

Surfactants are majorly comprise of hydrophobic tail groups of fatty alcohols, fatty acids, fatty amines, etc. obtained from petroleum origin and hydrophilic head group of sulphates, phosphates, quaternary ammonium salts, etc. Due to depletion of petroleum resources, the surfactant industry is looking into greener molecules and alternative renewable source like vegetable oils/fats, proteins and carbohydrates obtained from animal and plant-based sources ${ }^{1}$. Amino acid-based surfactants were reported by several researchers by reacting variety of pure amino acids (neutral, acidic, basic and aromatic, etc. or simple peptides) with several individual fatty acids or their mixtures with excellent surfactant properties like wetting, emulsifying power, calcium tolerance, solubilizing and foaming properties, and good mildness to the skin, safe ecology, and environmental friendly molecules along with biological properties ${ }^{2-4)}$. In addition, $N$-acyl amino acids were also exploited for use in many adhesive formulations, anti-corrosive applications and enantio-discriminating lyotropic liquid crystalline NMR solvents $^{5-7)}$. Amino acid-based surfactants are used in the separation of isomeric mixtures and chiral recognition ${ }^{8}$. Surfactants or surfactant solutions are also being used extensively in many chemical reactions as catalysts or as phase transfer catalysts and reaction mediums, etc. ${ }^{9,10)}$. Amino acid-based surfactants are being used in the preparation of organogels and hydrogels which are useful in personal care products, thickening agents in cosmetics, pharmaceuticals and other industrial applications ${ }^{11-13)}$.

Amino acids namely glycine, lysine, arginine, cysteine, leucine, isoleucine, phenylalanine, proline, tryptophan, tyrosine, serine, valine, alanine and protein hydrolysates

Abbreviations: FA: Fatty acid; MA: Malvalic acid, (8-9-cycylopropene octadecanoic acid); SA: Sterculic acid, (9-10-cyclopropene nonadecanoic acid); Pro: proline; NAPro: $N$-acyl proline; $\mathrm{C}_{8: 0}$-NAPro: $N$-octanoyl proline; $\mathrm{C}_{10: 0}-\mathrm{NAPro}: N$-decanoyl proline; $\mathrm{C}_{12: 0}$-NAPro: $N$-lauroyl proline; $\mathrm{C}_{14: 0}-\mathrm{NAPro}: N$-myristoyl proline; $\mathrm{C}_{16: 0}$-NAPro: $N$-palmitoyl proline; $\mathrm{C}_{18: 0}$-NAPro: $N$ stearoyl proline; $\mathrm{C}_{18: 1}$-NAPro: $N$-oleoyl proline; $\mathrm{C}_{18: 2}-\mathrm{NAPro}$ : $N$-linoleoyl proline; $\mathrm{C}_{20: 0}$-NAPro: $N$-cosanoyl proline; $\mathrm{C}_{20: 1^{-}}$ NAPro: $N$-cosenoyl proline; $\mathrm{C}_{22: 0}$-NAPro: $N$-docosanoyl proline; $\mathrm{C}_{24: 0}$-NAPro: $N$-tetracosanoyl proline.

\footnotetext{
*Correspondence to: Rachapudi Badari Narayana Prasad, Centre for Lipid Research, CSIR-Indian Institute of Chemical Technology (CSIR-IICT), Hyderabad 500007, Andhra Pradesh, INDIA

E-mail: rbnprasad@iict.res.in

Accepted September 14, 2015 (received for review April 1, 2015)

Journal of Oleo Science ISSN 1345-8957 print / ISSN 1347-3352 online

http://www.jstage.jst.go.jp/browse/jos/ http://mc.manusriptcentral.com/jjocs
} 
were used as head groups for the synthesis of amino acid surfactants in the laboratory studies as well as commercial applications. Vale et $a l .{ }^{14-16)}$ synthesized and studied the biological, interfacial and micellar properties of the amino acid-based cationic surfactants of varying head groups namely tyrosine, hydroxy proline, serine and lysine and different chain lengths (C12-C18). Hydroxy proline-based surfactants showed lower toxic with lower CMC values compared to others and commercial surfactants DTAB, SDS, HTAB. Even though mixed fatty acid-based surfactants are more economical, majority of the literature focused on the synthesis of amino acid-based surfactants using pure fatty acids and pure amino acids to study the basic surface, self-assembly and biological properties. $N$ Oleoyl proline showed superior surface activity, foaming characteristics and wetting ability compared to phenylalanine and isoleucine-based surfactants ${ }^{17)} . N$-Palmitoyl proline showed the higher antimicrobial activity and good wetting ability among the other sodium $N$-palmitoyl amino acids $^{18,19)}$. Especially $N$-lauroyl proline exhibited the higher calcium tolerance compared to other $N$-lauroyl amino acids $^{2)}$. Very few reports are available on the synthesis of amino acid-based surfactants using mixture of fatty acids along with single chain fatty alkyl groups with better surface-active properties ${ }^{20-23)}$.

Considering all these facts, we also synthesized the sodium $\mathrm{N}$-acyl isoleucines as anionic surfactants using a mixture of fatty acids obtained from vegetable oils, namely coconut, palm kernel, palm, jatropha, karanja, Sterculia foetida, castor and high oleic sunflower oils ${ }^{24}$. These vegetable oil-based surfactants exhibited better biological properties and superior surface active properties like calcium tolerance, critical micelle concentration $(C M C)$ and emulsion stability as compared to the reference surfactant, sodium lauryl sulphate(SLS). As a result of these studies, the mixture of fatty acids-based surfactants were prepared in this study by varying the amino acid head group isoleucine with proline. The present study also aimed to reveal the effects of the chain length and functionalities and the synergetic effect varied with the type of vegetable oil of these proline-based surfactants on their surface active properties and their cytotoxicity. These new proline-based surfactants find potential use in personal care, pharmaceuticals, household and industrial applications.

\section{EXPERIMENTAL}

\subsection{Materials and Methods}

Proline, sodium lauryl sulphate (SLS) other chemicals and solvents were purchased from M/s. SD Fine Chemicals, Mumbai, India. Oxalyl chloride was purchased from SigmaAldrich, St. Louis, MO, USA. Coconut, palm and high oleic sunflower were procured from local market Hyderabad,
India, and used without further purification. Karanja and Sterculia foetida (Java Olive) oils were extracted from their oilseeds with hexane using Soxhlet method. Silica gel (60-120 mesh) for column chromatography was purchased from M/s. Acme Synthetic Chemicals, Mumbai, India, and pre-coated TLC plates (silica gel $\mathrm{F}_{254}$ ) were purchased from Merck, Darmstadt, Germany.

Slip melting points (SMP) of synthesized compounds were determined using AOCS official method Cc 1-25, 1997. UV-visible spectrophotometer (Lambda 25, PerkinElmer, Shelton, CT, USA) was used to measure the absorbance. IR spectra were recorded on a FT-IR spectrophotometer (Perkin-Elmer, Model: Spectrum BX, Shelton, CT, USA) as thin film. All proton NMR spectra were recorded on $400 \mathrm{MHz}$ (Varian, Palo Alto, CA, USA) spectrophotometer (Model: INOVA 400) using TMS as internal standard. The fatty acid compositions of different oils are given as their corresponding fatty acid methyl esters (FAME ${ }^{25}$. The FAME's were analyzed using Agilent 6890 Gas chromatograph unit equipped with FID. Similarly, the column purified mixture of $N$-acyl prolines (NAPro) was protected as methyl ester with diazomethane and analyzed using GC-MS. The GC-MS analysis was performed with Agilent 6890 (Philadelphia, PA, USA) gas chromatograph connected to Agilent 5973 mass spectrophotometer at $70 \mathrm{eV}(\mathrm{m} / \mathrm{z}$ 50-600; source at $230^{\circ} \mathrm{C}$ and quadruple at $150^{\circ} \mathrm{C}$ ) in the EI mode with a HP-1 MS capillary column $(30 \mathrm{~m} \times 0.25 \mathrm{~mm} \times$ $0.5 \mu \mathrm{m})$.

\subsection{Synthesis of Sodium N-Acyl Prolines}

Sodium $N$-Acyl prolines were prepared by SchttoenBaumann reaction as shown in Scheme $1^{2)}$.

2.2.1 Typical procedure for the preparation of fatty acid mixtures from coconut oil ( $\mathrm{RCOOH})$

Fatty acid mixtures were prepared from vegetable oils by following our earlier reported method ${ }^{24)}$. Coconut oil (54.0 g, $80 \mathrm{mmol}$ ) was taken into 1 liter of three necked round bottom flask and to this, aqueous $\mathrm{NaOH}$ solution (11.2 g, $280 \mathrm{mmol}$ )was added drop wise with constant stirring. The temperature of the reaction mixture was raised to $90^{\circ} \mathrm{C}$ and these conditions were maintained for $4 \mathrm{~h}$. The progress of the reaction was monitored by micro TLC (hexane: ethyl acetate, 90:10, v/v) for the confirmation of triglyceride conversion into fatty acids. After confirmation, the contents were neutralized using $\mathrm{HCl}(6 \mathrm{~N})$. The fatty acid layer was separated and washed thoroughly with distilled water till neutral and dried under vacuum to obtain the mixtures of fatty acids $(49.8 \mathrm{~g}, 98.03 \%$ yield $) . \operatorname{IR}\left(v_{\max }\right.$, $\left.\mathrm{cm}^{-1}, \mathrm{CH}_{2} \mathrm{Cl}_{2}\right): 2925(\mathrm{br})$ and $1711(\mathrm{~s})$. Similarly, other fatty acid mixtures of palm, karanja, high oleic sunflower, and Sterculia foetida oils were prepared in 96-98\% yields.

2.2.2 Preparation of mixture of coconut fatty acyl chlorides $(\mathrm{RCOCl})$

Mixture of fatty acyl chlorides were prepared as de- 


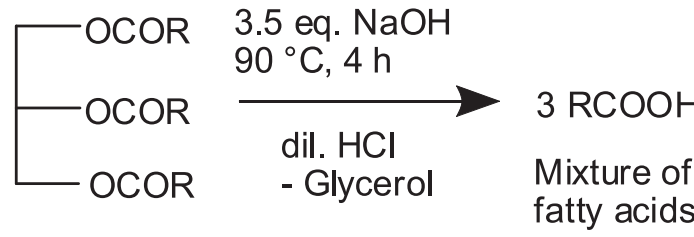

Triglyceride

\section{2 eq. $(\mathrm{COCl})_{2}$}

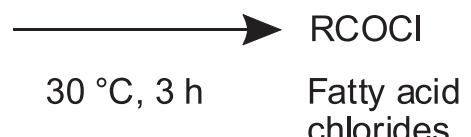<smiles>[R]C(=O)N1CCCC1C(=O)O[Na]</smiles>

Sodium $N$-acyl prolines

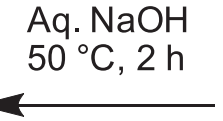

\section{$N$-Acyl prolines}<smiles>CCCCCCCCCC=CCCCCC1CC1=C1CC(CCCCCCCC)=C1CCCCCCC</smiles><smiles>CCCCCCC/C=C/CCCCCCCC</smiles><smiles>CCCCCCCCCCCCCCCCC</smiles><smiles>CCCCCCCCCCCCCCC</smiles><smiles>CCCCCCCCCCCCC</smiles>

Fatty acid side chains $\mathrm{R}=$<smiles>CCCCCCCCCCC</smiles><smiles>CCCCCCCCC</smiles>

$\mathrm{R}=$ Mixture of fatty acids from coconut, palm, karanja, sterculia and high oleic sunflower oils

Scheme 1 Synthesis of sodium $N$-acyl prolines.

scribed in the literature ${ }^{24)}$. Fatty acid mixture of coconut oil (10 g, $46.7 \mathrm{mmol})$ was taken in a two necked round bottomed flask and to this, oxalyl chloride $(7.12 \mathrm{~g}, 56.0 \mathrm{mmol})$ was added drop wise at $30^{\circ} \mathrm{C}$. The reaction mixture was stirred for $3 \mathrm{~h}$ at $30^{\circ} \mathrm{C}$ and excess oxalyl chloride was distilled out under vacuum after completion of reaction to obtain the coconut fatty acid chlorides ( $10.6 \mathrm{~g}, 99 \%$ yield). $\operatorname{IR}\left(v_{\max }, \mathrm{cm}^{-1}, \mathrm{CH}_{2} \mathrm{Cl}_{2}\right): 2925(\mathrm{~s})$ and $1800(\mathrm{~s})$. Similarly, fatty acid chlorides of karanja, high oleic sunflower, palm, and Sterculia foetida fatty acid mixtures were prepared in quantitative yields.

2.2.3 Typical procedure for the preparation of coconut $N$ acyl prolines (CNAPro)

Proline (5.0 g, $43.48 \mathrm{mmol}$ )was dissolved in $10 \%$ aqueous $\mathrm{NaOH}$ solution $(100 \mathrm{~mL})$ at $30^{\circ} \mathrm{C}$. To this, equivalent coconut fatty acyl chlorides $(10.13 \mathrm{~g})$ were added 
slowly drop wise and further stirred for $2 \mathrm{~h}$ at ambient temperature. After $2 \mathrm{~h}$, the mixture was acidulated with diluted sulfuric acid and the product was extracted with ethyl acetate $(3 \times 50 \mathrm{~mL})$. The ethyl acetate extracts were washed with brine solution and dried over anhydrous $\mathrm{Na}_{2} \mathrm{SO}_{4}$. The solvent was evaporated and the crude product was subjected to silica gel column chromatography using hexane/ethyl acetate $(90: 10, \mathrm{v} / \mathrm{v})$ as eluent to get the $N$-acyl prolines $(9.73 \mathrm{~g})$. The product was characterized by spectral techniques. Similarly, other $N$-acyl prolines of karanja, high oleic sunflower, palm, and Sterculia foetida fatty acid mixtures were prepared in quantitative yields.

Coconut N-acyl prolines (CNAPro): SMP $67.3^{\circ} \mathrm{C}$, Yield $75.1 \%$. IR $\left(v_{\max }, \mathrm{cm}^{-} 1, \mathrm{CH}_{2} \mathrm{Cl}_{2}\right): 3307,2926,2855,1718$, $1648,1542,1459$ and $1215 .{ }^{1} \mathrm{H}$ NMR $\left(\mathrm{CDCl}_{3}, \delta \mathrm{ppm}\right): 4.2-4.4$ (m, $\alpha$-CHR-) , 3.4-3.7 (m, -N-CH $\left.{ }_{2}^{-}\right)$, 1.8-2.3 (m, $\beta, \gamma-\mathrm{CH}_{2^{-}}$, $\left.-\mathrm{CO}-\mathrm{CH}_{2}-\right), 1.5-1.7\left(\mathrm{~m},-\mathrm{CO}-\mathrm{CH}_{2}-\mathrm{CH}_{2}\right), 1.2-1.3(\mathrm{~m}$, alkyl $\left.-\mathrm{CH}_{2}{ }^{-}\right)$and $0.8-0.9\left(\mathrm{t},-\mathrm{CH}_{3}, J=6.79 \mathrm{~Hz}\right)$. GC-MS $(\mathrm{EI}, 70 \mathrm{eV})$ : $m / \approx \mathrm{C}_{8: 0^{-}}$NAPro: $255\left(\mathrm{M}^{+}\right), \mathrm{C}_{10: 0^{-}}$NAPro: $283\left(\mathrm{M}^{+}\right), \mathrm{C}_{12: 0^{-}}$ NAPro: $311\left(\mathrm{M}^{+}\right), \mathrm{C}_{14: 0}$-NAPro: $339\left(\mathrm{M}^{+}\right), \mathrm{C}_{16: 0^{-}}$NAPro: 367 $\left(\mathrm{M}^{+}\right), \mathrm{C}_{18: 0}$-NAPro: $395\left(\mathrm{M}^{+}\right)$and $\mathrm{C}_{18: 1}$-NAPro: $393\left(\mathrm{M}^{+}\right)$.

Palm fatty $N$-acyl prolines (PNAPro): SMP $62.4^{\circ} \mathrm{C}$, Yield $67.5 \%$. IR $\left(v_{\max }, \mathrm{cm}^{-1}, \mathrm{CH}_{2} \mathrm{Cl}_{2}\right): 3315,2924,1710$, 1631, 1540, 1449 and $1202 .{ }^{1} \mathrm{H} \mathrm{NMR}\left(\mathrm{CDCl}_{3}, \delta \mathrm{ppm}\right): 5.4-5.6$ $(\mathrm{m},-\mathrm{CH}=\mathrm{CH}-)$, 4.5-4.7 (m, $\alpha-\mathrm{CHR}-)$, 3.4-3.7 $\left(\mathrm{m},-\mathrm{N}-\mathrm{CH}_{2}-\right)$, 1.9-2.3 (m, $\beta, \Gamma-\mathrm{CH}_{2^{-}}$, $\left.-\mathrm{CO}-\mathrm{CH}_{2}-\right), 1.5-1.7\left(\mathrm{~m},-\mathrm{CO}-\mathrm{CH}_{2}-\mathrm{CH}_{2}\right)$, $1.1-1.3\left(\mathrm{~m}\right.$, alkyl $\left.-\mathrm{CH}_{2^{-}}\right)$and $0.8-0.9\left(\mathrm{t},-\mathrm{CH}_{3}, J=6.79 \mathrm{~Hz}\right)$. GC-MS (EI, $70 \mathrm{eV}): m / z \mathrm{C}_{14: 0^{-N}}$ NAPro: $339\left(\mathrm{M}^{+}\right), \mathrm{C}_{16: 0}$-NAPro: $367\left(\mathrm{M}^{+}\right), \mathrm{C}_{18: 0}$-NAPro: $395\left(\mathrm{M}^{+}\right), \mathrm{C}_{18: 1} \mathrm{1}^{-N A P r o:} 393\left(\mathrm{M}^{+}\right)$and $\mathrm{C}_{18: 2^{-}}$NAPro: $391\left(\mathrm{M}^{+}\right)$.

Karanja fatty $N$-acyl prolines (KNAPro): SMP $57.4^{\circ} \mathrm{C}$, Yield $72.1 \%$. IR $\left(v_{\max }, \mathrm{cm}^{-1}, \mathrm{CH}_{2} \mathrm{Cl}_{2}\right): 3398,2928,1715$, $1631,1546,1449$ and $1202 .{ }^{1} \mathrm{H} \mathrm{NMR}\left(\mathrm{CDCl}_{3}, \delta \mathrm{ppm}\right): 5.2-5.4$ $(\mathrm{m},-\mathrm{CH}=\mathrm{CH}-)$, 4.4-4.6 (m, $\alpha$-CHR- $), 3.4-3.6\left(\mathrm{~m},-\mathrm{N}-\mathrm{CH}_{2^{-}}\right)$, 2.7-3.1 (m, $\left.\beta, \gamma-\mathrm{CH}_{2^{-}}\right), 2.1-2.4\left(\mathrm{t},-\mathrm{CO}-\mathrm{CH}_{2^{-}}, J=7.55 \mathrm{~Hz}\right)$, $1.8-2.0\left(\mathrm{~m},-\mathrm{CH}_{2}-\mathrm{CH}=\mathrm{CH}-\right), 1.5-1.7\left(\mathrm{~m},-\mathrm{CO}-\mathrm{CH}_{2}-\mathrm{CH}_{2}\right)$, 1.0-1.2 (m, alkyl $\left.-\mathrm{CH}_{2^{-}}\right)$and $0.8-0.9\left(\mathrm{t},-\mathrm{CH}_{3}, J=6.97 \mathrm{~Hz}\right)$. GC-MS (EI, $70 \mathrm{eV}): m / z \mathrm{C}_{16: 0}$-NAPro: $367\left(\mathrm{M}^{+}\right), \mathrm{C}_{18: 0}$-NAPro: $395\left(\mathrm{M}^{+}\right), \mathrm{C}_{18: 1}$-NAPro: $393\left(\mathrm{M}^{+}\right), \mathrm{C}_{18: 2^{-}}$NAPro: $391\left(\mathrm{M}^{+}\right)$, $\mathrm{C}_{20: 0}$-NAPro: $423\left(\mathrm{M}^{+}\right), \mathrm{C}_{20: 1}$-NAPro: $421\left(\mathrm{M}^{+}\right), \mathrm{C}_{22: 0}$-NAPro: $451\left(\mathrm{M}^{+}\right)$and $\mathrm{C}_{24: 0^{-}}$NAPro: $479\left(\mathrm{M}^{+}\right)$.

Sterculia fatty $N$-acyl prolines (SNAPro): SMP $43.2^{\circ} \mathrm{C}$, Yield 58.2\%. IR $\left(v_{\max }, \mathrm{cm}^{-1}, \mathrm{CH}_{2} \mathrm{Cl}_{2}\right): 3382,2930,2852$, 1714, 1609, 1542, 1458 and $1197 .{ }^{1} \mathrm{H} \mathrm{NMR}\left(\mathrm{CDCl}_{3}, \delta \mathrm{ppm}\right)$ :

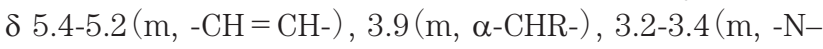
$\left.\mathrm{CH}_{2^{-}}\right), 2.2\left(\mathrm{~m}, \beta, \gamma-\mathrm{CH}_{2^{-}}\right), 1.8-2.0\left(\mathrm{t},-\mathrm{CO}-\mathrm{CH}_{2^{-}}, J=7.54 \mathrm{~Hz}\right)$, 1.1-1.6 (m, alkyl - $\mathrm{CH}_{2^{-}}$, - $\left.\mathrm{CO}-\mathrm{CH}_{2}-\mathrm{CH}_{2}-\right)$ and 0.8-0.9 (t, $-\mathrm{CH}_{3}, J$ $=6.79 \mathrm{~Hz})$. GC-MS $(\mathrm{EI}, 70 \mathrm{eV}): \mathrm{m} / z \mathrm{C}_{16: 0}$-NAPro: $367\left(\mathrm{M}^{+}\right)$, $\mathrm{C}_{18: 0^{-}}$NAPro: $395\left(\mathrm{M}^{+}\right), \mathrm{C}_{18: 1^{-}}$-NAPro: $393\left(\mathrm{M}^{+}\right) \mathrm{C}_{18: 2^{-}}$-NAPro: $391\left(\mathrm{M}^{+}\right), \mathrm{C}_{\mathrm{MA}^{-}}$-NAPro: $391\left(\mathrm{M}^{+}\right)$and $\mathrm{C}_{\mathrm{SA}^{-}}$-NAPro: $405(90.1)$ $\left(\mathrm{M}^{+}\right)$.

High oleic sunflower fatty $N$-acyl prolines (HNAPro): SMP $32.6{ }^{\circ} \mathrm{C}$, Yield $64.5 \%$. IR $\left(v_{\max }, \mathrm{cm}^{-1}, \mathrm{CH}_{2} \mathrm{Cl}_{2}\right): 3384$, 2932, 2854, 1712, 1618, 1530, 1461 and $1215 .{ }^{1} \mathrm{H}$ NMR
$\left(\mathrm{CDCl}_{3}, \delta \mathrm{ppm}\right): 5.3-5.5(\mathrm{~m},-\mathrm{CH}=\mathrm{CH}-), 4.5-4.6(\mathrm{~m}, \alpha-\mathrm{CHR}-)$, 3.4-3.7 (m, $\left.-\mathrm{N}-\mathrm{CH}_{2^{-}}\right), 2.2-2.4\left(\mathrm{~m}, \beta, \gamma-\mathrm{CH}_{2^{-}}\right)$, 1.9-2.1 (t, $-\mathrm{CO}-$ $\left.\mathrm{CH}_{2^{-}}, J=6.54 \mathrm{~Hz}\right), 1.5-1.7\left(\mathrm{~m},-\mathrm{CO}-\mathrm{CH}_{2}-\mathrm{CH}_{2}{ }^{-}\right), 1.1-1.4(\mathrm{~m}$, alkyl- $\left.\mathrm{CH}_{2^{-}}\right)$and $0.8-0.9\left(\mathrm{t},-\mathrm{CH}_{3}, J=6.79 \mathrm{~Hz}\right)$. GC-MS (EI, 70 $\mathrm{eV}): m / 2 \mathrm{C}_{16: 0}$-NAPro: $367\left(\mathrm{M}^{+}\right), \mathrm{C}_{18: 0}$-NAPro: $395\left(\mathrm{M}^{+}\right)$, $\mathrm{C}_{18: 1}$-NAPro: $393\left(\mathrm{M}^{+}\right)$and $\mathrm{C}_{18: 2}$-NAPro: $391\left(\mathrm{M}^{+}\right)$.

2.2.4 Preparation of sodium $N$-acyl prolines of coconut fatty acids (NaNAPro)

Sodium $N$-acyl prolines were prepared using a method reported in the literature ${ }^{24)}$. Briefly, coconut $N$-acyl prolines (5.0 g, $16.77 \mathrm{mmol}$ ) were dissolved in ethanol and to this equivalent aqueous $\mathrm{NaOH}(0.671 \mathrm{~g})$ solution was added. The contents were stirred for $2 \mathrm{~h}$ at $50^{\circ} \mathrm{C}$ then filtered and the solvent was evaporated to get corresponding sodium $N$-acyl prolines ( $\sim 99 \%$ yield). Similarly, other sodium $N$-acyl prolines of karanja, Sterculia foetida, palm, and high oleic sunflower fatty acid mixtures were prepared in quantitative yields.

\subsection{Surface Active Properties of Sodium N-Acyl Prolines}

\subsubsection{Wetting power}

The Draves-Clarkson method as described in IS specification(BIS-1185, Bureau of Indian Standards, New Delhi, 1957) was used for estimating the wetting time of sodium $\mathrm{N}$-acyl prolines ${ }^{24)}$.

2.3.2 Calcium tolerance

Modified Hart's method was used for the determination of calcium tolerance of sodium $N$-acyl prolines ${ }^{24,26)}$.

\subsubsection{Foaming power}

Foaming properties of sodium $\mathrm{N}$-acyl prolines were determined using pour foam apparatus at ambient temperature according to reported method ${ }^{24,27)}$.

2.3.4 Emulsion stability

Emulsion stability was determined according to a method described in the literature ${ }^{24,28)}$.

2.3.5 CMC determination by surface tension method

Surface tension was measured using K100MK2 Processor Tensiometer (Krüss, GmbH, Hamburg, Germany) as reported in the literature ${ }^{24)}$.

\subsection{In vitro cytotoxicity of Sodium $\mathrm{N}$-Acyl Prolines}

The cytotoxicity of the sodium $N$-acyl prolines was assessed by using the MTT assay according to reported $\operatorname{method~}^{29,30}$.

\section{RESULTS AND DISCUSSION}

\subsection{Synthesis of sodium $\mathrm{N}$-acyl prolines}

Currently, all surfactant industries are exploring the renewable molecules of vegetable oils/fats, proteins and carbohydrates due to their low toxicity and high biodegradability compared to petroleum chemicals-based surfactants. In the present study, fatty acid mixtures of palm, coconut, 
karanja, Sterculia and high oleic sunflower oils were prepared using alkaline hydrolysis method (Scheme 1) in 96-98\% yield. Mixture of fatty acids obtained from five vegetable oils contain mainly three types of functionalities, namely saturated, unsaturated and cyclopropene fatty acids. Coconut fatty acids were of medium and short chain with $90 \%$ saturation. Palm and karanja fatty acids were long chain with 50 to $78 \%$ unsaturation. High oleic sunflower fatty acids were $90 \%$ unsaturated. Sterculia fatty acids comprised of $50 \%$ cyclopropene fatty acids. The fatty acid composition of five oils is analyzed by gas chromatography (GC) and given in Table 1. They were chosen for the study of functionality and synergetic effect of fatty acid mixtures on their surface-active properties and cytotoxicity and are also cost-effective as compared to pure fatty substrates. In the second step, all the fatty acid mixtures were converted into fatty acid chlorides with oxalyl chloride in quantitative yield. The conversion was monitored by IR spectroscopy. The third step of Scheme 1 is the preparation of $N$-acyl prolines by the Schotten-Baumann reaction with fatty acid chlorides and proline at $\mathrm{pH}$ 10. The physical state of the products NAPro's was semi-solids except the high oleic sunflower fatty acyl derivatives which was liquid at room temperature due to more unsaturation. The slip melting points of $\mathrm{N}$-acyl prolines of coconut, palm, high oleic sunflower, karanja and Sterculia foetida were found in the range of $32.6-67.3^{\circ} \mathrm{C}$. The GC-MS analysis of methyl esters of $N$-acyl prolines revealed that there was no much change in the fatty acid composition observed before and after the $N$-acylation. In the final step, the sodium $N$-acyl prolines were prepared by treating with aqueous $\mathrm{NaOH}$ and confirmed by IR spectroscopy. The IR spectra of all the sodium $N$-acyl prolines showed the disappearance of the -CO- band around $1700 \mathrm{~cm}^{-1}$ and the appearance of two strong bands near 1600 and $1450 \mathrm{~cm}^{-1}$ corresponding to the carboxylate group of sodium salt.

\subsection{Surface Active Properties of Sodium N-Acyl Prolines}

Aqueous solutions $(0.1 \mathrm{wt} \%)$ of sodium $N$-acyl prolines were used for the evaluation of surfactant properties at ambient temperature. The surface active properties were evaluated using standard methods and compared with SLS. All the surface properties are useful from a commercial point of view for any newly synthesized surfactants. The aim of this study is to see the effect of fatty acyl moiety functionality of vegetable oil on these surface active properties. The results presented in this work are the mean values of three independent measurements and are shown in Table 2.

3.2.1 Calcium tolerance

Calcium tolerance property will provide the efficiency of surfactants towards hard water and acidic/alkali solutions. Generally, the anionic surfactants are negatively charged ions and more sensitive to hard water and acidic solutions

Table 1 Fatty acid composition of seed oils used in this study*.

\begin{tabular}{lccccccccccccc}
\hline \multirow{2}{*}{\multicolumn{1}{c}{ Vegetable oil }} & \multicolumn{10}{c}{ Fatty acid (wt \%) } \\
\cline { 2 - 12 } & $\mathrm{C}_{8: 0}$ & $\mathrm{C}_{10: 0}$ & $\mathrm{C}_{12: 0}$ & $\mathrm{C}_{14: 0}$ & $\mathrm{C}_{16: 0}$ & $\mathrm{C}_{18: 0}$ & $\mathrm{C}_{18: 1}$ & $\mathrm{C}_{18: 2}$ & $\mathrm{C}_{20: 0}$ & $\mathrm{C}_{20: 1}$ & $\mathrm{C}_{22: 0}$ & $\mathrm{C}_{22: 1}$ & $\mathrm{C}_{24: 0}$ \\
\hline Coconut & 6.5 & 5.8 & 47.5 & 19.7 & 8.9 & 3.0 & 6.7 & 1.9 & - & - & - & - & - \\
Palm & - & - & - & 1.9 & 44.3 & 4.6 & 38.7 & 10.5 & - & - & - & - & - \\
Karanja & - & - & - & - & 9.8 & 7.8 & 54.5 & 17.0 & 1.9 & 1.1 & 1.2 & 5.1 & 1.6 \\
Sterculia & - & - & - & - & 25.4 & 4.7 & 12.8 & 7.7 & - & - & & & - \\
High oleic sunflower & - & - & - & - & 3.2 & 5.1 & 81.9 & 9.8 & - & - & - & - & - \\
\hline
\end{tabular}

$*$ Sterculia oil contains malvalic acid $(\mathrm{MA})=5.5 \%$ and sterculic acid $(\mathrm{SA})=43.9 \%$.

Table 2 Surface Active Properties of Sodium N-Acyl Prolines*.

\begin{tabular}{|c|c|c|c|c|c|c|c|c|}
\hline \multirow[b]{2}{*}{ Surfactant } & \multirow{2}{*}{$\begin{array}{l}\text { Average } \\
\text { MW of } \\
\text { SNAAA }\end{array}$} & \multirow{2}{*}{$\begin{array}{l}\text { Calcium } \\
\text { tolerance } \\
(\mathrm{ppm})\end{array}$} & \multirow{2}{*}{$\begin{array}{l}\text { Wetting } \\
\text { time } \\
\text { (s) }\end{array}$} & \multirow{2}{*}{$\begin{array}{l}\text { Surface } \\
\text { tension } \\
(\mathrm{mN} / \mathrm{m})\end{array}$} & \multicolumn{2}{|c|}{ Foam height $(\mathrm{cm})$} & \multicolumn{2}{|c|}{ Emulsion stability time (s) } \\
\hline & & & & & Initial & After 5 min & $\begin{array}{c}10 \mathrm{~mL} \\
\text { separation }\end{array}$ & $\begin{array}{c}20 \mathrm{~mL} \\
\text { separation }\end{array}$ \\
\hline CNAPro & 312.1 & $15.1 \pm 1.3$ & $5.6 \pm 0.2$ & $34.7 \pm 0.3$ & $12.0 \pm 0.3$ & $8.0 \pm 0.4$ & $534 \pm 5$ & $984 \pm 12$ \\
\hline PNAPro & 370.5 & $81.6 \pm 0.7$ & $10.6 \pm 0.3$ & $31.0 \pm 0.1$ & $14.5 \pm 0.1$ & $9.5 \pm 0.2$ & $325 \pm 7$ & $547 \pm 9$ \\
\hline KNAPro & 384.5 & $78.5 \pm 1.1$ & $14.2 \pm 0.6$ & $31.9 \pm 0.2$ & $13.5 \pm 0.2$ & $12.5 \pm 0.3$ & $255 \pm 2$ & $482 \pm 11$ \\
\hline SNAPro & 391.0 & $94.9 \pm 1.5$ & $9.5 \pm 0.2$ & $31.2 \pm 0.3$ & $13.5 \pm 0.1$ & $11.0 \pm 0.1$ & $199 \pm 8$ & $349 \pm 5$ \\
\hline HNAPro & 385.2 & $82.3 \pm 0.9$ & $13.4 \pm 0.3$ & $32.7 \pm 0.1$ & $12.5 \pm 0.2$ & $11.0 \pm 0.1$ & $322 \pm 6$ & $597 \pm 6$ \\
\hline SLS & 288 & $8.8 \pm 0.6$ & $4.5 \pm 0.2$ & $28.9 \pm 0.2$ & $16.0 \pm 0.3$ & $15.0 \pm 0.2$ & $216 \pm 5$ & $438 \pm 11$ \\
\hline
\end{tabular}

* $0.1 \mathrm{wt} \%$ surfactant solution at $27^{\circ} \mathrm{C} ; \mathrm{MW}=$ Molecular Weight. 
as compared to nonionic and cationic surfactant solutions $^{31}$. All the sodium $N$-acyl prolines were evaluated for their calcium tolerance property and tabulated in Table 2 . All the sodium $N$-acyl prolines exhibited better calcium tolerance as compared to the commercial SLS (8.8 ppm). CNAPro (15.1 ppm) exhibited lower calcium tolerance as compared to other $\mathrm{N}$-acyl prolines. The calcium tolerance of short and medium chain fatty acid-based compounds was lower than the cyclopropene and long chain unsaturated fatty acids. The calcium tolerance increased with an increase in the polarity of the amino acid head group from isoleucine (2.5 -56.9 ppm) to proline (15.1- $94.9 \mathrm{ppm})^{24)}$. Calcium tolerance of mixture of sodium $N$-acyl prolines except CNAPro was found to be superior as compared to pure sodium $N$-oleoyl proline $(75.9 \mathrm{ppm})^{17)}$, sodium $N$-palmitoyl proline $(2.5 \mathrm{ppm})^{19)}$, and was inferior to $N$-lauroyl proline $(>1000 \mathrm{ppm})^{2)}$.

\subsubsection{Wetting power}

Wetting power mainly depends on the adsorption of surfactant molecule at the surface of solid or liquid. The adsorption will vary with the structure of head group and tail group of surfactant molecule. Good wetting agents are good detergents. Anionic surfactants are reported as good wetting agents in textile industry ${ }^{32)}$. All the sodium $N$-acyl prolines (5.6-14.2 s) prepared in this study were inferior in wetting power as compared to SLS (Table 2). However, the wetting ability of coconut fatty acid derivatives $(5.6 \mathrm{~s})$ was almost similar to SLS $(4.5 \mathrm{~s})$. The wetting ability was superior in case of short and medium chain saturated fatty acids as compared to unsaturated fatty acid-based products. The wetting power of cyclopropene fatty acid-based products was superior as compared to long chain unsaturated fatty acids and was inferior to saturated fatty acids. The prolinebased products exhibited superior wetting ability as compared to isoleucine-based products $(5.0-22.3 \mathrm{~s})^{24)}$. The wetting ability of mixture of coconut $(5.6 \mathrm{~s})$, palm $(10.6 \mathrm{~s})$ and high oleic sunflower sodium $N$-acyl prolines (13.4 s) was superior as compared to their corresponding rich pure individual fatty acyl derivatives of sodium $N$-lauroyl proline $(9 \mathrm{~s})^{2)}$, sodium $N$-palmitoyl proline $(20.7 \mathrm{~s})^{19)}$ and sodium $N$-oleoyl proline $(14.7 \mathrm{~s})^{17)}$.

3.2.3 Surface tension

In general, the surfactants detergency is higher at critical micelle concentration. Detergency increases with increasing the concentration of the monomeric surfactant which is generally unaffected by the presence or absence of micelles. Based on surface tension values, the compounds can be predicted for different applications. For example, solutions having surface tension less than $40 \mathrm{mN} /$ $\mathrm{m}$ can be exploited as wetting agents $\mathrm{s}^{32}$. Surface tension of the synthesized sodium $N$-acyl prolines was measured at $0.1 \mathrm{wt} \%$ solutions $(31.0-34.7 \mathrm{mN} / \mathrm{m})$ and these values were less than $40 \mathrm{mN} / \mathrm{m}$. A total of five surface tension measurements for each solution were determined and the results are presented as their mean value in Table 2. In general, the surface activity increased with an increase in the length of fatty alkyl group of the same analogue. CNAPro exhibited lower surface activity as compared to others and SLS $(28.9 \mathrm{mN} / \mathrm{m})$. All these amino acid surfactants (except SNAPro) were showed higher surface tension values (about $1.8-3.3 \mathrm{mN} / \mathrm{m}$ ) at $0.1 \mathrm{wt} \%$ (>CMC) compared to surface tension values at their $\mathrm{CMC}\left(\gamma_{\mathrm{cmc}}\right.$, Table 3$)$. The surface tension of surfactant increased with increasing concentration above CMC. This trend is reverse to the conventional surfactants and this erratic behavior is unknown to us. This behavior was not found in case of pure and mixture of $N$-acyl phenylalanines and isoleucines head groups ${ }^{17,24,30)}$. 3.2.4 Foaming characteristics

Both high and low foaming agents are useful for a wide range of industrial and household applications ${ }^{33)}$. In general, foaming power increases with an increase in the alkyl chain length of same analogue ${ }^{34}$. The foaming characteristics of all the sodium $N$-acyl prolines are inferior compared to SLS (Table 2). Short and medium chain saturated fatty acyl derivatives (CNAPro) exhibited inferior foaming power and foam stability as compared to cyclopropene and

Table $3 C M C$ and thermodynamic properties of sodium $N$-acyl prolines*.

\begin{tabular}{ccccccc}
\hline Surfactant & $\begin{array}{c}\gamma_{\mathrm{cmc}} \\
(\mathrm{mN} / \mathrm{m})\end{array}$ & $\begin{array}{c}C M C \\
(\mathrm{mmol} / \mathrm{L})\end{array}$ & $\mathrm{pC}_{20}$ & $\begin{array}{c}\Pi_{\mathrm{cmc}} \\
(\mathrm{mN} / \mathrm{m})\end{array}$ & $\begin{array}{c}\Gamma_{\max } \times 10^{10} \\
\left(\mathrm{~mol} / \mathrm{cm}^{2}\right)\end{array}$ & $\begin{array}{c}A_{\min } \\
\left(\AA^{2}\right)\end{array}$ \\
\hline CNAPro & 32.4 & $1.27 \times 10^{-1}$ & 3.89 & 39.6 & 3.68 & 45.1 \\
PNAPro & 28.4 & $1.25 \times 10^{-2}$ & 4.90 & 43.6 & 4.96 & 33.4 \\
KNAPro & 30.1 & $2.06 \times 10^{-3}$ & 5.68 & 41.9 & 4.99 & 33.2 \\
SNAPro & 36.8 & $2.8 \times 10^{-3}$ & 5.55 & 35.2 & 3.24 & 51.2 \\
HNAPro & 29.4 & $4.61 \times 10^{-3}$ & 5.33 & 42.6 & 4.24 & 39.1 \\
SLS & 33.7 & 8.3 & 2.08 & 38.3 & 3.96 & 41.9 \\
\hline
\end{tabular}

*Surface tension measured at $27^{\circ} \mathrm{C} ; \gamma_{\mathrm{cmc}}$, surface tension value at the $C M C ; C M C$, critical micelle concentration; $\Pi_{\mathrm{cmc}}$, effectiveness of surface tension reduction; $\Gamma_{\max }$, maximum surface excess; $\mathrm{pC}_{20}$, Negative logarithm of surfactant concentration is required to reduce the surface tension of pure water by 20 units; $A_{\min }$, minimum surface area per molecule. 
unsaturated long chain fatty acid derivatives. Foam stability of proline-based compounds is superior as compared to isoleucine derivatives ${ }^{24)}$ and inferior as compared to SLS. 3.2.5 Emulsion stability

Similar to foam properties, emulsions occurs in many chemical process along with foam. Emulsions are also desirable and some are not. Emulsions are used in many application niche areas such as cosmetics, agriculture, paints, food, photography, leather, drug-delivery systems, etc. ${ }^{32,35}$. The emulsion stability of the sodium $N$-acyl prolines was determined and presented in Table 2. In general, the emulsifying power increases with an increase in the methylene group of fatty alkyl chain of same analogue due to increase in solubility of alkyl group in oil ${ }^{2}$. The emulsion stability of the sodium $N$-acyl prolines except SNAPro (199 s) was superior as compared to SLS (216 s) and therefore, all these products can find application as good long term stable emulsifying agents. The emulsion stability time for $10 \mathrm{~mL}$ and $20 \mathrm{~mL}$ separation of the sodium $N$-acyl prolines varied from 199 to $534 \mathrm{~s}$ and 349 to $984 \mathrm{~s}$, respectively. The increasing order of the emulsion stability with respect to fatty acid alkyl chain is as follows: cyclopropene fatty acid $<$ unsaturated long chain fatty acid $<$ short and medium chain fatty acids. The emulsion stability of proline-based surfactants is as follows: SNAPro $<$ KNAPro $<$ PNAPro $<$ HNAPro $<$ CNAPro. The emulsion stability of mixture of sodium $N$-acyl prolines was superior as compared to pure individual fatty acyl prolines $(30-213 \mathrm{~s})^{2,19)}$. The emulsion stability decreased with an increase in the polarity of the amino acid head group from isoleucine to proline due to lower hydrophobicity ${ }^{24)}$.

3.2.6 $C M C$ and thermodynamic properties by Kruss tensiometer

$C M C$ can define the surfactant efficiency and it is an important surfactant property occurring in the bulk aqueous solution after completion of monolayer formation at air-water interface area. The surfactants are more efficient with lower $C M C$ values. $C M C$ values of these sodium $N$-acyl prolines were determined as shown in Fig. 1 from intersection points of average surface tension (SFT) vs. log concentration (ln C) values and represented in Table 3. Lower $C M C$ values $(0.00206-0.127 \mathrm{mmol} / \mathrm{L})$ were observed with an increase in the longer unsaturated alkyl chain derivatives and all the products were found to have lower $C M C$ values as compared to $\operatorname{SLS}(8.3 \mathrm{mmol} / \mathrm{L})$. CNAPro comprised of $50 \%$ of $\mathrm{C}_{12}$ fatty acyl chains and the values were comparable with SLS which is also a $\mathrm{C}_{12}$ alkyl compound. $C M C$ values of these compounds were one fold inferior as compared to SLS due to mixture of long chain fatty acid $\left(\mathrm{C}_{14}, \mathrm{C}_{16}\right.$, and $\left.\mathrm{C}_{18}\right)$ derivatives and also lower than the pure $N$-lauroyl proline $(0.74 \mathrm{mmol} / \mathrm{L})^{2)}$. The $C M C$ value of palm oil-based product, namely PNAPro was found to be 0.0125 $(\mathrm{mmol} / \mathrm{L})$ which was also lower than the pure $N$-palmitoyl proline $(0.095 \mathrm{mmol} / \mathrm{L})^{18)}$. Generally, an increase in the hy-

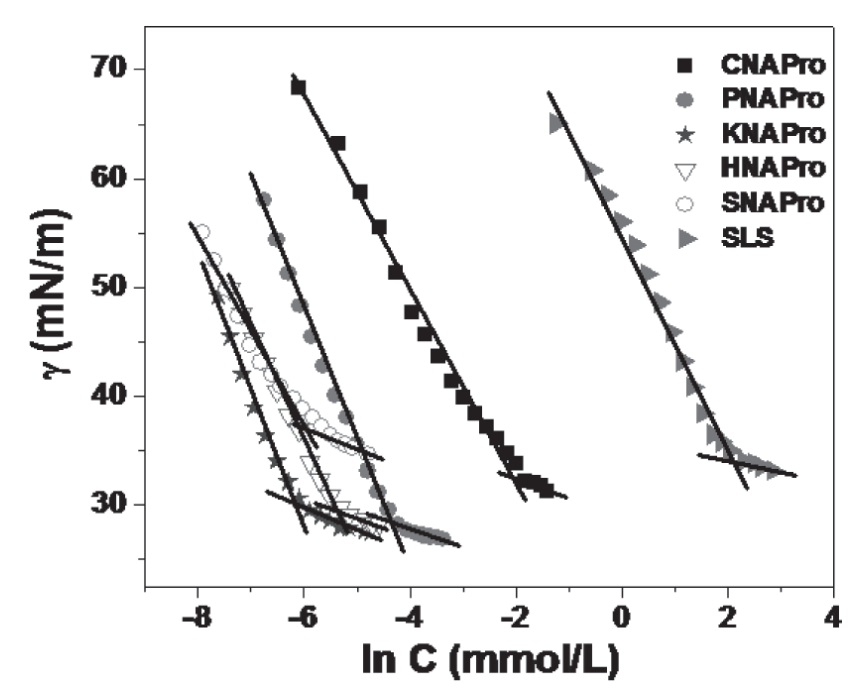

Fig. 1 Plots of $\gamma$ vs. $\ln \mathrm{C}(\mathrm{mmol} / \mathrm{L})$ of sodium $N$-acyl prolines.

drophobicity of amino acid or fatty acid decreases the $C M C$ value. Three fold lower order of magnitude of $C M C$ values of SNAPro $(0.0028 \mathrm{mmol} / \mathrm{L})$, KNAPro $(0.00206 \mathrm{mmol} / \mathrm{L})$ and HNAPro $(0.00461 \mathrm{mmol} / \mathrm{L})$ were observed as compared to SLS $(8.3 \mathrm{mmol} / \mathrm{L})$ and lower than pure $N$-oleoyl proline $\left.(0.0048 \mathrm{mmol} / \mathrm{L})^{17}\right)$.

Surface tension reduction efficiency $\left(\mathrm{pC}_{20}=\right.$ negative logarithm of surfactant concentration is required to reduce the surface tension of pure water by 20 units) values were measured from the plots of Fig. 1. All the surfactants (except SLS) $\mathrm{pC}_{20}(>3)$ values (3.89-5.68) were efficient surfactants ${ }^{36)}$ and the $\mathrm{pC}_{20}$ values also increased with an increase in the long chain unsaturated derivatives from coconut to palm, high oleic sunflower, Sterculia and karanja fatty acid-based surfactants. All the products having higher $\mathrm{pC}_{20}$ values were most efficient as compared to SLS as well as coconut fatty acids-based product having short and medium chain fatty acids. Thermodynamic properties of these sodium $N$-acyl prolines including the effectiveness of surface tension reduction $\left(\Pi_{\mathrm{cmc}}\right)$, maximum surface excess concentration $\left(\Gamma_{\max }\right)$, minimum surface area per molecule $\left(A_{\min }\right)$ at air-water interface were determined using following equations ${ }^{37,38)}$.

$$
\Pi_{\mathrm{cmc}}=\gamma_{0}-\gamma
$$

where $\gamma_{0}$ is pure water surface tension, $\gamma$ is surface tension at CMC.

$$
\begin{aligned}
& \Gamma_{\max }=-(1 / \mathrm{n} R T)(\mathrm{d} \gamma / \mathrm{d} \ln \mathrm{C}) \\
& A_{\min }=1 / N \cdot \Gamma_{\max }
\end{aligned}
$$

where $R$ is the gas constant $(8.314 \mathrm{~J} / \mathrm{mol} . \mathrm{K}), T$ is absolute temperature, $\gamma$ is surface tension, $\mathrm{C}$ is surfactant concentration and $N$ is Avogadro's number. The value of $\mathrm{n}$ is taken to be 2 as there is one counter ion associated with one 
ionic head group ${ }^{36)}$.

The maximum surface tension reduction of a surfactant was observed at micelle concentration and it revealed the surfactant effectiveness $\left(\Pi_{\mathrm{cmc}}\right)$. Higher the $\Pi_{\mathrm{cmc}}$ value surfactant was the most effective. All the product solutions except SNAPro $(35.2 \mathrm{mN} / \mathrm{m})$ had the similar $\Pi_{\text {cmc }}$ values $(39.6-43.6 \mathrm{mN} / \mathrm{m})$. There was no change in the effectiveness of isoleucine head group $(40.3-42.34 \mathrm{mN} / \mathrm{m})$ to proline head group surfactants ${ }^{24)}$. Similarly, the surface excess $\left(\Gamma_{\max }\right)$ values of the surfactants also did not show much difference with changes in the functionality of the hydrophobic group at air-water interface. However, among these the sterculia fatty acid based surfactant exhibited lower concentration as compared to others. The minimum area per molecule at the air-water interface gives the information on the degree of packing and the orientation of the adsorbed surfactant molecule. $A_{\min }$ and $\Gamma_{\max }$ values are inter-related and inversely proportionate to each other. Sterculia fatty acids-based surfactant exhibited higher $A_{\min }$ value at airwater interface area as compared to others due to cyclopropene fatty acid derivatives. This indicates that the molecules were less tightly packed at the air/water interface for the cyclopropene fatty alkyl surfactants. The head group effect on molecular packing of micelles $\left(A_{\text {min }}\right)$ was observed in all these surfactants.

\subsection{In Vitro Cytotoxicity Assessment}

Generally, the amino acid-based surfactants exhibited lower irritancy towards skin cells and eye cells and also less toxic towards aquatic species as compared to the conventional surfactants, SDS, HTAB and TGB ${ }^{4,39)}$. Cytotoxicity of the amino acid-based surfactants is dependent on structure of the surfactant of head group or hydrophobic group or size of the counter ion ${ }^{3,40)}$. Based on in vitro and in vivo studies, amino acid-based surfactants may offer use in pharmaceutical, skin care and cosmetic applications due to their lower irritancy potential, less toxic and high biodegradability $^{41,42}$. Lipoamino acids were used as potential anti-inflammatory agents ${ }^{43}$. Gopal et $_{\text {al. }}{ }^{44)}$ reported the cytotoxicity of series of $\mathrm{N}$-sapienoyl $\left(\mathrm{C}_{16: 1}\right)$ amino acids and among those $N$-sapienoyl leucine exhibited the higher activity towards the selective tumor cell lines. In the present study, cytotoxicity of the sodium $N$-acyl prolines was determined against the different available cancer cell lines up to a concentration of $50 \mu \mathrm{g} / \mathrm{mL}$. The concentration of the compounds at which $50 \%$ of the cell growth was inhibited $\left(\mathrm{IC}_{50}\right)$ was calculated and depicted in Table 4. PNAPro exhibited moderate cytotoxicity towards MDA-MB-231 (37.5 $\mu \mathrm{g} / \mathrm{mL})$ and MCF-7 $(36.5 \mu \mathrm{g} / \mathrm{mL})$ cell lines. SNAPro showed promising activity towards A549 $(12.46 \mu \mathrm{g} / \mathrm{mL})$ and MDAMB-231 $(2.03 \mu \mathrm{g} / \mathrm{mL})$ cell lines and almost equal activity of standard doxorbucin $(0.58 \mu \mathrm{g} / \mathrm{mL})$ towards the cell lines, MCF-7 $(0.78 \mu \mathrm{g} / \mathrm{mL})$ and HeLa $(0.62 \mu \mathrm{g} / \mathrm{mL})$. HNAPro exhibited promising activity towards only $\mathrm{HeLa}(2.32 \mu \mathrm{g} / \mathrm{mL})$ cell line. CNAPro and KNAPro compounds did not show cytotoxicity at the tested concentrations. Compound SNAPro (cyclopropene fatty acids-based product) exhibited superior activity as compared to other $N$-acyl prolines, reported mixture of $\mathrm{N}$-acyl isoleucines and also $\mathrm{N}$-sapienoyl $\left(\mathrm{C}_{16: 1}\right)$ amino $\operatorname{acids}^{24,44)}$.

\section{CONCLUSIONS}

Proline-based surfactants were synthesized from a mixture of fatty acids obtained from vegetable oils and proline in $58-75 \%$ yields. They were characterized by spectral and chromatographic techniques. All the products were evaluated for surface-active properties and cytotoxicity and interpreted with respective to change in the functionalities in the fatty acids. All the surfactants exhibited better calcium tolerance and emulsifying power as compared to SLS. CNAPro exhibited almost similar wetting ability as compared to SLS. Lower CMC values (0.00206 $0.127 \mathrm{mmol} / \mathrm{L}$ ) and higher $\mathrm{pC}_{20}$ values (3.89-5.68) showed the efficiency of sodium $N$-acyl prolines. Foaming properties, surface tension and wetting ability of proline-based surfactants were inferior as compared to SLS. These low

Table 4 In vitro cytotoxicity of sodium $N$-acyl prolines.

\begin{tabular}{cccccc}
\hline \multirow{2}{*}{ Compound } & \multicolumn{5}{c}{$\mathrm{IC}_{50}(\mu \mathrm{g} / \mathrm{mL})$} \\
\cline { 2 - 6 } & $\mathrm{A} 549$ & MDA-MB-231 & MCF-7 & HeLa & Neuro2a \\
\hline PNAPro & - & 37.5 & 36.5 & - & - \\
SNAPro & 12.46 & 2.03 & 0.78 & 0.62 & - \\
HNAPro & - & - & - & 2.32 & - \\
Doxorubicin & 0.58 & $<0.58$ & 0.58 & $<0.58$ & 0.65 \\
\hline
\end{tabular}

A549: Human alveolar adenocarcinoma epithelial cells (ATCC No. CCL-185);

HeLa: Human cervical cancer cells (ATCC No. CCL-2);

MDA-MB-231: Human breast adenocarcinoma cells (ATCC No. HTB-26);

MCF7: Human breast adenocarcinoma cells (ATCC No. HTB-22);

Neuro2a: Mouse neuroblastoma cell line (ATCC No. CCl-131); - = No activity. 
foaming surfactants along with lower $C M C$ values can be used as alternative to petroleum based surfactants and also as stable emulsifiers in many industrial process and cleansing applications. Compounds like PNAPro, HNAPro and SNAPro exhibited promising cytotoxicity towards the tested tumor cell lines.

\section{ACKNOWLEDGEMENTS}

M. Sreenu acknowledge to Department of Science and Technology, Government of India, New Delhi, for providing the research fellowship. P. Sujitha is grateful to the Council of Scientific and Industrial Research (CSIR), New Delhi, for the award of SRF.

The authors have declared no conflict of interest.

\section{References}

1) Nnanna, I. A.; Xia, J. Protein Based Surfactants: Synthesis, Physicochemical Properties, and Applications; Surfactant Science Series, Vol. 101, Marcel Dekker, New York, USA (1998).

2) Mhaskar, S. Y.; Prasad, R. B. N.; Lakshminarayana, G. Synthesis of $N$-acyl amino acids and correlation of structure with surfactant properties of their sodium salts. J. Am. Oil Chem. Soc. 67, 1015-1019 (1990).

3) Pinazo, A.; Pons, R.; Perez, L.; Infante, M. R. Amino acids as raw material for biocompatible surfactants. Ind. Eng. Chem. Res. 50, 4805-4817(2011).

4) Chandra, N.; Tyagi, V. K. Synthesis, properties and applications of amino acids based surfactants: A review. J. Disp. Sci. Technol. 34, 800-808(2013).

5) Schimmel, K. F.; Jones, D. W.; Desai, U. C. N-Acyl amino acid compositions and their use as adhesion promoters, US Patent, Pat. No. 6096813, (2000).

6) Baczko, K.; Larpent, C.; Lesot, P. New amino acidbased anionic surfactants and their use as enantiodiscriminating lyotropic liquid crystalline NMR solvents. Tetrahedron: Asym. 15, 971-982(2004).

7) Negm, N. A.; Zaki, M. F. Synthesis and characterization of some amino acid derived schiff bases bearing nonionic species as corrosion inhibitors for carbon steel in 2N HCl. J. Disp. Sci. Technol. 30, 649-655(2009).

8) Billiot, F. H.; Billiot, E.; Warner, I.M. Comparison of monomeric and polymeric amino acid based surfactants for chiral separations. J. Chrom. A 922, 329-338 (2001).

9) Khan, M. N; Arifin, Z. J. Effects of inorganic ions on rate of alkaline hydrolysis of phthalimide in the presence of cationic micelles. Perkin Trans. 2, 2503-2510 (2000).

10) Roy, S.; Das, D.; Dasgupta, A.; Mitra, R. N.; Das, P. K.
Amino acid based cationic surfactants in aqueous solution: Physicochemical study and application of supramolecular chirality in ketone reduction. Langmuir 21, 10398-10404(2005).

11) Suzuki, M.; Sato, T.; Kurose, A.; Shirai, H.; Hanabusa, K. New low-molecular weight gelators based on L-valine and L-isoleucine with various terminal groups. Tetrahedron Lett. 46, 2741-2745 (2005).

12) Roy, S.; Das, P. K. Antibacterial hydrogels of amino acid-based cationic amphiphiles. Biotechnol. Bioeng. 100, 756-764 (2008).

13) Suzuki, M.; Hanabusa, K. L-Lysine-based low-molecular-weight gelators. Chem. Soc. Rev. 38, 967-975 (2009).

14) Silva, S. G.; Rodriguez-Borges, J. E.; Marques, E. F.; Vale, M. L. C. Towards novel monomeric efficient surfactants based on serine, tyrosine and hydroxy proline: synthesis and micellization properties. Tetrahedron 65, 4156-4164(2009).

15) Brito, R. O.; Marques, E. F.; Silva, S. G.; Vale, M. L. C.; Gomes, P.; Araujo, M. J.; Rodriguez-Borges, J. E.; Infante, M. R.; Garcia, M. T.; Ribos, I.; Vinardell, M. P.; Mitjans, M. Physicochemical and toxicological properties of novel amino acid-based amphiphiles and their spontaneously formed catanionic vesicles. Colloids Surf. B: Biointerfaces 72, 80-87 (2009).

16) Brito, R. O.; Silva, S. G.; Fernandes, R. M. F.; Marques, E. F.; Enrique-Borges, J.; Vale, M. L. C.; Enhanced interfacial properties of novel amino acid-derived surfactants: Effects of headgroup chemistry and of alkyl chain length and unsaturation. Colloids Surf. B: Biointerfaces 86, 65-70 (2011).

17) Sreenu, M.; Nayak, R. R.; Prasad, R. B. N.; Sreedhar, B. Synthesis, surface and micellar properties of sodium $N$-oleoyl amino acids. Colloids Surf. A: Physicochem. Eng. Aspects 449, 74-81 (2014).

18) Gerova, M.; Rodrigues, F.; Lamere, J. F.; Dobrev, A.; Fery-Forgues, S. Self-assembly properties of some chiral $N$-palmitoyl amino acid surfactants in aqueous solution. J. Colloid Interface Sci. 319, 526-533 (2008).

19) Sreenu, M.; Nayak, R. R.; Prasad, R. B. N.; Poornachandra, Y.; Kumar, C. G. Surface and antimicrobial properties of sodium $N$-palmitoyl amino acid-based surfactants. J. Disp. Sci. Technol. 36, 765-771(2015).

20) Martinez, V.; Cosini, E.; Mitjans, M.; Pinazo, A.; Vinardell, M. P. Evaluation of eye and skin irritation of arginine-derivative surfactants using different in vitro endpoints as alternatives to the in vivo assays. Toxicol. Lett. 164, 259-267 (2006).

21) Soo, E. L.; Salleh, A. B.; Basri, M.; Rahman, R. N. Z. R. A.; Kamaruddin, K. Optimization of the enzyme-catalyzed synthesis of amino acid-based surfactants from palm oil fractions. J. Biosci. Bioeng. 95, 361-367 (2003). 
22) Ronde, C.; Alric, I.; Mouloungui, Z.; Blanco, J.; Silvestre, F. Synthesis and properties of lipoamino acid-fatty acid mixtures: Influence of the amphiphilic structure. J. Surf. Deterg. 12, 269-275(2009).

23) Sanchez, L.; Martinez, V.; Infante, M. R.; Mitjans, M.; Vinardell, M. P. Hemolysis and antihemolysis induced by amino acid-based surfactants. Toxicol. Lett. 169, 177-184 (2007).

24） Sreenu, M.; Rao, B. V. S. K.; Prasad, R. B. N.; Sujitha, P.; Kumar, C. G. Synthesis, surface and biological properties of sodium $N$-acyl isoleucines. Eur. J. Lipid Sci. Technol. 116, 193-206 (2014).

25) Christie, W. W. Lipid Analysis, 2nd Edn, Pergamon, Oxford, (1982).

26) Wikes, B. G.; Wickert, J. N. Synthetic aliphatic penetrants. Ind. Eng. Chem. 29, 1234-1239 (1937).

27) Ross, J.; Miles, G. D. An apparatus for comparison of foaming properties of soaps and detergents. Oil Soap 18, 99-103 (1941).

28) Subrahmanyam, V. V. R.; Achaya, K. T. Structure and surfactance evaluation of ricinoleyl alcohol. J. Chem. Eng. Data 6, 38-41 (1961).

29) Mosmann, T. Rapid colorimetric assay for cellular growth and survival: application to proliferation and cytotoxicity assays. J. Immunol. Methods 65, 55-63 (1983).

30) Sreenu, M.; Prasad, R. B. N.; Sujitha, P.; Kumar, C. G. Synthesis and surface-active properties of sodium $N$ acylphenylalanines and their cytotoxicity. Ind. Eng. Chem. Res. 54, 2090-2098(2015).

31) Mishra, M.; Muthuprasanna, P.; Surya Prabha, K.; Sobhita Rani, P.; Satish Babu, I. A.; Sarath Chandiran, I.; Arunachalam, G.; Shalini, S. Basics and potential applications of surfactants-a review. Int. J. PharmTech Res. 1, 1354-1365 (2009).

32) Schramm, L. L.; Stasiuk, E. N.; Marangoni, D. G. Surfactants and their applications. Annu. Rep. Prog. Chem., Sect. C: Phys. Chem. 99, 3-48(2003).

33) Azira, H.; Tazerouti, A.; Canselier, J. P. Study of foaming properties and effect of the isomeric distribution of some anionic surfactants. J. Surf. Deterg. 11, 279286 (2008).

34) Zocchi, G.; in: Broze, G. (Ed.), Handbook of Detergents; Part A-Surfactant Properties; Surfactant Sci- ence Series, 82, Marcel Dekker, New York, USA (1999).

35) Garti, N.; Bisperink, C. Double emulsions: Progress and applications. Curr. Opin. Colloid Interface Sci. 3, 657-667 (1998).

36) Rosen, M. J. Surfactants and Interfacial Phenomena, 4th Edn., Wiley Interscience, New York, USA, (2004).

37) Mukherjee, $P$. The nature of the association equilibria and hydrophobic bonding in aqueous solutions of association colloids. Adv. Colloid Interface Sci. 1, 242275 (1967).

38) Moulik, S. P.; Haque, M. E.; Jana, P. K.; Das, A. R. Micellar properties of cationic surfactants in pure and mixed states. J. Phys. Chem. 100, 701-708(1996).

39) Sanchez, L.; Mitjans, M.; Infante, M. R.; Vinardell, M. P. Potential irritation of lysine derivative surfactants by hemolysis and HaCaT cell viability. Toxicol. Lett. 161, 53-60 (2006).

40) Sanchez, L.; Mitjans, M.; Infante, M. R.; Vinardell, M. P. Assessment of the potential skin irritation of lysinederivative anionic surfactants using mouse fibroblasts and human keratinocytes as an alternative to animal testing. Pharm. Res. 21, 1637-1641(2004).

41) Sanchez, L.; Mitjans, M.; Infante, M. R.; Vinardell, M. P. Determination of interleukin-1 $\alpha$ in human NCTC 2544 keratinocyte cells as a predictor of skin irritation from lysine-based surfactants. Toxicol. Lett. 167, 40-46 (2006).

42) Benavides, T.; Mitjans, M.; Martınez, V.; Clapes, P.; Infante, M. R.; Clothier, R. H.; Vinardell, M. P. Assessment of primary eye and skin irritants by in vitro cytotoxicity and phototoxicity models: An in vitro approach of new arginine-based surfactant-induced irritation. Toxicology 197, 229-237 (2004).

43) Burstein, S. H.; Adams, J. K.; Bradshaw, H. B.; Fraioli, C.; Rossetti, R. G.; Salmonsen, R. A.; Shaw, J. W.; Walker, J. M.; Zipkind, R. E.; Zurier, R. B. Potential anti-inflammatory actions of the elmiric (lipoamino)acids. Bioorg. Med. Chem. 15, 3345-3355(2007).

44) Gopal, S. C.; Kaki, S. S.; Rao, B. V. S. K.; Poornachandra, Y.; Kumar, C. G.; Prasad, R. B. N. Synthesis of novel lipoamino acid conjugates of sapienic acid and evaluation of their cytotoxicity activities. J. Oleo Sci. 63, 717-722 (2014). 